\title{
THE STATE OF THE ENVIRONMENTAL AWARENESS OF STUDENTS FROM POLAND, SLOVAKIA AND UKRAINE - SELECTED RESULTS
}

\author{
Karolina CYNK ${ }^{1}$ \\ University of Rzeszow, Rzeszów, Poland
}

\begin{abstract}
In the article was presented results of international researches about environmental consciousness. The project was realized in 2015. The main purpose of this article is to describe the level of environmental knowledge, values and attitudes among university students from Central Eastern Europe. In introduction of article was defined concept of environmental awareness. The research problem is question: What are differences in the state of environmental awareness between respondents living in the Poland, Slovakia and Ukraine? In the first part text was presented methodology of the conducted research. The second part of the article concerns the analysis of the collected data. On the basis of the conducted research it can maintain that the students of Central and Eastern Europe generally declared interest the state of the environment. The overall outcome of the research leads to the conclusion that the highest proportion of the respondents who declared interest in the environmental protection came from Slovakia. The fact that in their opinion it should care about the environment more than the students from Poland and Ukraine may result from the higher level of the environmental awareness.
\end{abstract}

\section{INTRODUCTION}

The term "environmental awareness", as a fact of social and cultural life, doesn't have a long history. Its emergence happened only at the beginning of the $20^{\text {th }}$ century and it was associated with the difficulties caused by the pollution of the natural environment, which soon became an important social problem. As a

1 Corresponding author: University of Rzeszow, Rejtana st 16c, 35-001 Rzeszów, Poland, e-mail: rss@ur.edu.pl, tel.+46601962050 
term, the environmental awareness is difficult to define and evaluate. This derives from the fact that awareness makes an integral whole and, therefore, it is difficult to separate environmental spheres from the activities and the way of thinking of a man. The term "environmental awareness" which, according to D. Kielczewski, means: "the attitude of a man towards the natural environment, the set of information and beliefs about the environment as well as the system of values towards the environment which determines our behaviour" [6]. According to other researches environmental awareness "has three concepts that include emotional, attitude and practice of sustainability awareness" [4]. In Papuzinski's opinion environmental awareness was appeared with the formation of social associations in situation criticism of industrial society [8].

The social researchers attempting to study the issues pertaining to the environment don't use sociological theories. The general sociology has at its disposal no satisfying concepts, which could concern human behaviours and attitudes towards environment. A result of this is the perpetuating dissonance between the researches and the theory. It manifests in situation: the execution of numerous studies without theoretical foundations. This type of situation can remark for example in the articles about environmental awareness: Hassan et al. [4], Altin et al. [1], Zhang et al. [9], Liu et al. [5], Cetin, Nisanci [2] or Özden [7]. The main purpose of this article is to describe the level of environmental knowledge, values and attitudes among university students from Poland, Slovakia and Ukraine. The research problems are the questions: What level of environmental awareness is represented by students? Are there any differences in the levels of environmental consciousness between respondents living in European Union countries and in the Ukraine, which is not a Community member?

The article concerns current social subject. The main reason that author undertake research is the getting worse state of the environment. The negative changes shows report prepared by United Nations Environment Programme [3] It is important problem because the environment influences on the quality of human life.

In the Ukraine, Slovakia and Poland were realized the quantitative researches. An auditory questionnaire-based survey was carried out to collect relevant data. The research was conducted on the purposive sample of students. Countries and universities were selected using the snowball technique. Specialities were selected randomly, and the survey was realized among those students who according to their study programme had classes at the given time. 


\section{METHODOLOGY}

The extent to which the environmental awareness of a society is developed can only be determined by means of scientific research. One of such sociological research was conducted from $13^{\text {th }}$ April to $19^{\text {th }}$ May 2015. The subject of the research was: „Environmental values in the awareness of the students of humanities and life sciences from the selected European countries". The main objective of the research was to learn about the state of the environmental awareness of the young citizens of Central and Eastern Europe. In order to reach this objective it was necessary to collect data on: students' knowledge of the environmental protection and threats to the environment, "the environmental values" of the respondents and their declared attitudes towards the natural environment. It was also necessary to place the rules and norms of "the environmental culture" among other social values appreciated by the students. The most important problems, that resulted from the subject of the research, were formulated in the following way: Do students have fundamental knowledge of the environment and the environmental protection or whether they just express common opinions that are present in a public space? To what extent are the respondents aware of the threats to the environment? What attitudes towards the natural environment are most commonly presented by the respondents? What place, among other principles valued by the students, is taken by "the environmental values"? The above research problems correspond to the initial research hypotheses formulated in the following way: The respondents, to a greater extent, represent popular and common opinions about the environmental protection rather than elementary scientific knowledge of it. They are aware of the threats to the environment in the world and the level of this awareness is high. In general, they declare to manifest pro-environmental attitude in everyday life, however, it is demonstrated in easy activities that do not require a lot of work. The students tend to think that "the environmental values" play an important role in their lives, which are to be proven by the interest in the state of the natural environment they declared to have.

The research was conducted on the purposive sample of 390 students. The sample included students of the University of Rzeszow (Poland), University of Presov (Slovakia) and Rivne State Humanitarian University (Ukraine). Universities were selected using the snowball sampling technique. In the research each country was represented by the group of 130 students. In each group half of the students studied humanities or social studies and the other half - life sciences. The respondents were the students of the $1^{\text {st }}$ cycle or engineering studies (apart from the $1^{\text {st }}$ year students) and of the $2^{\text {nd }}$ cycle studies. In the case of humanities and social studies the students were enrolled in the following fields of study: social work, cultural studies, political science, andragogy and history and in the case of life sciences - food technology and human nutrition, 
biology, ecology, environmental protection and agriculture. To describe the sample more accurately it needs to be mentioned that $77.9 \%$ of the respondents were female and only $22.1 \%$ - male. $59.5 \%$ of the respondents were between 20 22 years old, $28.7 \%$ - between $23-25$ years old, $9.7 \%$ - between $17-19$ years old and $2.1 \%$ were over 25 years old. When it comes to the religious beliefs, the majority of the respondents, i.e. $61.7 \%$, claimed to be catholic, $29.6 \%$ orthodox, 3.6\% claimed to be non-religious, $2.8 \%$ - protestants and $2.3 \%$ declared to follow other religions. Taking into account the variable: place of residence, the majority of the respondents, i.e. $60.2 \%$, lived in the countryside, $15.4 \%$ - in the city up to 49999 residents, $13.4 \%$ - in the city up to $99999,5.9 \%$ - in the city up to 199999 residents and 5.1\% - in the city over 200000 residents. When it comes to the variable: self-assessment of the financial situation, $66.6 \%$ of the respondents claimed that their financial resources were good enough to meet their everyday needs, $15.0 \%$ claimed to be in a good financial situation, $14.2 \%$ described themselves as those who had to save money on everyday basis, $3.6 \%$ have a really good financial situation and $0.5 \%$ live in luxury. Taking into account the variable: political views, the vast majority of the respondents, i.e. $68.9 \%$, were not able to specify their political views, $8.0 \%$ declared to have the right wing views, $4.7 \%$ - centre-right, $4.4 \%$ - left wing, $4.1 \%$ - centrist, $3.9 \%$ - other views, $2.1 \%$ - centre-left, $1.6 \%$ - radical right wing, $1.3 \%$ declared that they did not have any political views and $1.0 \%$ declared to have radical left wing views. Finally, when it comes to the variable: study cycle, $72.8 \%$ of the respondents were $1^{\text {st }}$ cycle or engineering students and $27.2 \%$ were $2^{\text {nd }}$ cycle students. Such characterization of the sample was prepared for the descriptive purposes only. As the groups of the respondents from each country were quite homogenous, the article, apart from the variable: the country in which the respondents live, addresses each question without taking into account any other sociodemographic features. Including any additional criteria would not result in obtaining any particularly interesting information, neither would they contribute to obtaining more reliable results of the research. On purpose it was chosen respondents who study in the similar social character spaces. The country in which the students live is the independent variable and the aim was explored whether the developing of the environmental awareness is included in the teaching programmes of the Central and Eastern European countries.

In order to solve the research problems the method of auditorium questionnaire was used. The research tool, used in the research, was the survey questionnaire with 18 closed and semi-open questions. The questionnaire was translated into the native language of the respondents. In order to verify the research tool it have been conducted pilot surveys among polish students. The selected questions and data are presented below. 


\section{ANALYSIS OF RESULTS FROM EMPIRICAL RESEARCH}

Obtained data were used for relevant calculations in the IBM SPSS Statistics software, and the level of statistical significance was adopted at $p=0.05$. Some questions and independent variables were nominal, and their analysis required the use of a chi-squared test to examine the relationship between the two qualitative variables. The variable used in the analysis is the country of residence. The sample was rather homogeneous, so the country of live the most suitable to examine differences in the opinions of students.

Table. 1. Data on deviant behaviour of other people towards the natural environment (data expressed in \%)

\begin{tabular}{|c|c|c|c|}
\hline \multicolumn{4}{|c|}{ Did you witness any illegal rubbish disposal in the past month? } \\
\hline 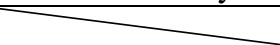 & Poland & Slovakia & Ukraine \\
\hline yes, definitely & 43.4 & 44.2 & 54.7 \\
\hline yes, I think so & 31.8 & 25.6 & 32.8 \\
\hline no, I don't think so & 15.5 & 23.3 & 7.8 \\
\hline no, definitely & 9.3 & 6.2 & 4.7 \\
\hline difficult to say & 0 & 0.8 & 0 \\
\hline \multicolumn{4}{|c|}{ Did you witness burning rubbish at home in the past month? } \\
\hline yes, definitely & 29.7 & 34.1 & 22.8 \\
\hline yes, I think so & 46.1 & 23.0 & 23.6 \\
\hline no, I don't think so & 18.8 & 26.2 & 23.6 \\
\hline no, definitely & 4.7 & 15.9 & 27.6 \\
\hline difficult to say & 0.8 & 0.8 & 2.4 \\
\hline \multicolumn{4}{|c|}{ Did you witness the use of chemicals in farming in the past month? } \\
\hline yes, definitely & 16.4 & 22.2 & 30.7 \\
\hline yes, I think so & 34.4 & 42.1 & 38.6 \\
\hline no, I don't think so & 24.2 & 25.4 & 16.5 \\
\hline no, definitely & 15.6 & 8.7 & 8.7 \\
\hline difficult to say & 9.4 & 1.6 & 5.5 \\
\hline \multicolumn{4}{|c|}{ Did you witness wasting of food in the past month? } \\
\hline yes, definitely & 53.8 & 59.4 & 36.1 \\
\hline yes, I think so & 34.6 & 28.9 & 37.7 \\
\hline no, I don't think so & 8.5 & 9.4 & 19.7 \\
\hline no, definitely & 3.1 & 0.8 & 4.9 \\
\hline difficult to say & 0 & 1.6 & 1.6 \\
\hline \multicolumn{4}{|c|}{ Did you witness wasting of electricity, paper, water in the past month? } \\
\hline yes, definitely & 45.7 & 58.9 & 43.7 \\
\hline yes, I think so & 35.7 & 34.1 & 34.9 \\
\hline no, I don't think so & 16.3 & 5.4 & 16.7 \\
\hline no, definitely & 1.6 & 1.6 & 3.2 \\
\hline
\end{tabular}




\begin{tabular}{|c|c|c|c|}
\hline difficult to say & 0.8 & 0 & 1.6 \\
\hline \multicolumn{3}{|c|}{ Did you witness animal abuse in the past month? } \\
\hline yes, definitely & 7.0 & 15.2 & 10.6 \\
\hline yes, I think so & 9.4 & 12.0 & 13.8 \\
\hline no, I don't think so & 36.7 & 39.2 & 30.1 \\
\hline no, definitely & 45.3 & 31.2 & 43.9 \\
\hline difficult to say & 1.6 & 2.4 & 1.6 \\
\hline
\end{tabular}

Source: own data [10]

The information presented in table 1 provides an insight into the environment of life of the respondents. It also presents the level of their sensitivity towards deviant behaviour that occurs in their communities. The presented data show that the vast majority of the respondents (which can be worrying) have recently witnessed various types of behaviour that is harmful to the natural environment. The exception is the last variable, i.e. "animal abuse", which majority of the respondents did not witness in the past month. When analysing the data on the first variable, we need to notice that the vast majority of the Ukrainian students said that they had witnessed illegal rubbish disposal. The same opinion was also expressed by a large number of Polish and Slovak students, however, the proportion here was adequately lower. As the result of the chi-squared test the following value was obtained $\chi^{2}(8)=17.423 ; p=0.026$. The results lead to the formulation of the hypothesis according to which the variable: the country in which the respondents live correlates with students' declarations that they had witnessed illegal rubbish disposal. As the value of the Pearson's Contingency Coefficient $\mathrm{C}=0.208$, the adjusted value of the coefficient $\mathrm{C}=0.243$, the strength of the relationship between the variables is classified as moderate.

In the case of the variable: "burning rubbish at home", we arrive at the conclusion that such behaviour was most frequently noticed by the Polish students, less frequently - by the Slovak students, whereas the majority of the respondents from Ukraine have not witnessed such phenomenon recently. In this case the value of the chi-squared test was $\chi^{2}(8)=41.101 ; p<0.05$. Thereby, the dependence between the variables is statistically significant, which means that we can formulate the hypothesis according to which: the country in which the respondents live determines students' declarations that they had witnessed inappropriate waste disposal. In this case the value of the Contingency Coefficient $\mathrm{C}=0.312$, the adjusted value of the coefficient $\mathrm{C}=0.365$, therefore the strength of the relationship between the variable is also classified as moderate. In the case of the use of chemicals in farming, such activities were most frequently witnessed by the Ukrainian students, slightly less frequently by the Slovak students and least frequently by the Polish students. At this point it needs to be pointed out that $66.9 \%$ of the Ukrainian students, $49.2 \%$ of the Slovak students and $64.3 \%$ of the Polish students lived in the countryside on permanent 
basis. Therefore, we can arrive at the conclusion that organic farming is, to a great extent, popular in the rural areas of Poland. The obtained value of the chi-squared test was $\chi^{2}(8)=20.045 ; p=0.010$. Thereby, there is a statistically significant relationship between the variable: they country in which the respondents live and students' declarations that they had witnessed the use of chemicals in farming. As the value of the Contingency Coefficient $\mathrm{C}=0.224$, the adjusted value of the coefficient $\mathrm{C}=0.262$, the strength of the relationship is also classified as moderate.

Another serious problem concerns wasting of food. According to students' declarations, such behaviour was witnessed by a great number of the respondents from Poland and Slovakia and only by a slightly lower proportion, i.e. nearly $3 / 4$, of the respondents from Ukraine. This may result from the fact that modern societies do not have any difficulties in meeting their existential needs. However, the negative result of such situation is the lack of respect for food and food production and also, indirectly, for the natural environment. In the case of this and the following variable, the distribution of the answers made it impossible to conduct the chi-squared test.

Another example of deviant behaviour is wasting of electricity, paper and water. Nearly every student from Slovakia declared to have witnessed such phenomenon. The same opinion was expressed by only a slightly lower proportion of Polish and Ukrainian respondents. When we compare wasting of electricity, paper and water to wasting of food, it turns out that Slovak and Ukrainian respondents more frequently witnessed wasting of electricity, paper and water, whereas Polish students - of food.

As previously stated, the last variable, i.e. "animal abuse", is the only behaviour which was not selected that often. The highest proportion of the respondents who witnessed such behaviour came, once again, from Slovakia, the lowest from Poland. Most likely, Slovak students are the most sensitive to animals suffering from the hand of a man. The value of the chi-squared test was $\chi^{2}(8)=10.586 ; p=0.226$. The obtained values lead to the rejection of the hypothesis according to which the variable: students' declarations that they had witnessed animal abuse depend on the country in which respondents live. Therefore, the dependence between the variables is not statistically significant.

Table. 2. Data illustrating the level of student's knowledge of the state of the environment (data expressed in \%)

\begin{tabular}{|c|c|c|c|}
\hline \multicolumn{4}{|c|}{ Do you think that the state of the natural environment? } \\
\hline is improving & Poland & Slovakia & Ukraine \\
\hline doesn't change & 4.6 & 3.1 & 0.8 \\
\hline is deteriorating as a result of human activity & 6.8 & 3.1 & 2.3 \\
\hline
\end{tabular}




\begin{tabular}{|l|c|c|c|}
\hline $\begin{array}{l}\text { is deteriorating as a result of natural } \\
\text { changes which take place regardless of a } \\
\text { man }\end{array}$ & 2.3 & 0.8 & 1.6 \\
\hline $\begin{array}{l}\text { is deteriorating both - as a result of human } \\
\text { activity and of natural changes }\end{array}$ & 26.2 & 23.3 & 43.8 \\
\hline difficult to say & 0 & 3.9 & 1.6 \\
\hline
\end{tabular}

Source: own data [10]

The distribution of the answers presented in table 2 makes it difficult to decide whether there is a correlation between the variable: the country in which the respondents live and the variable: knowledge of the state of the natural environment. The opinion that the state of the natural environment is deteriorating as a result of human activity was selected by the highest proportion of the respondents from each country. Much lower proportion of the respondents thought that the state of the natural environment was deteriorating both - as a result of human activity and of natural changes. All other options were selected by a low proportion of the respondents. The data presented above lead to the conclusion that although the respondents selected the correct option (that the state of the natural environment is deteriorating), human activity is not the only factor which affects the natural environment. Changes that take place without human interference also play an important role. The highest proportion of students who gave the correct answer came from Ukraine.

Table. 3. Data illustrating the state of ,the environmental imagination" of the respondents (data expressed in \%)

\begin{tabular}{|c|c|c|c|}
\hline \multicolumn{5}{|c|}{ Does water pollution worry you? } \\
\hline & Poland & Slovakia & Ukraine \\
\hline yes, definitely & 46.2 & 70.5 & 58.4 \\
\hline yes, I think so & 48.5 & 23.3 & 36.8 \\
\hline no, I don't think so & 3.1 & 5.4 & 2.4 \\
\hline no, definitely & 0.8 & 0.8 & 0.8 \\
\hline difficult to say & 1.5 & 0 & 1.6 \\
\hline \multicolumn{5}{|c|}{ Does air pollution worry you? } \\
\hline yes, definitely & 46.2 & 71.3 & 60.2 \\
\hline yes, I think so & 46.9 & 25.6 & 37.5 \\
\hline no, I don't think so & 6.9 & 3.1 & 0.8 \\
\hline difficult to say & 0 & 0 & 1.6 \\
\hline \multicolumn{5}{|c|}{ Does soil pollution worry you? } \\
\hline yes, definitely & 36.4 & 59.7 & 38.7 \\
\hline yes, I think so & 44.2 & 31.0 & 43.5 \\
\hline no, I don't think so & 16.3 & 7.0 & 10.5 \\
\hline no, definitely & 1.6 & 0 & 1.6 \\
\hline difficult to say & 1.6 & 2.3 & 5.6 \\
\hline
\end{tabular}

Source: own data [10] 
Thanks to the analysis of the data presented in table 3, we can state that vast majority of the respondents, regardless of the country in which they live, declared that they worried about water, air and soil pollution. The only difference, which can be observed, is a slightly lower proportion of the respondents who worry about soil pollution. Therefore, we can formulate the following hypothesis: the country in which the respondents live does not significantly differentiate students' opinions about the polluted elements of the inanimate nature.

Table 4. Data illustrating the importance given to the environmental protection by the respondents (data expressed in \%)

\begin{tabular}{|c|c|c|c|}
\hline \multicolumn{4}{|c|}{$\begin{array}{c}\text { Do you think that the activities in favour of the environmental protection are mor } \\
\text { important that economic development? }\end{array}$} \\
\hline & Poland & Slovakia & Ukraine \\
\hline yes, definitely & 14.1 & 36.2 & 18.1 \\
\hline yes, I think so & 30.5 & 36.9 & 37.0 \\
\hline no, I don't think so & 38.3 & 18.5 & 26.8 \\
\hline no, definitely & 6.3 & 0.8 & 4.7 \\
\hline difficult to say & 10.9 & 7.7 & 13.4 \\
\hline \multicolumn{4}{|c|}{$\begin{array}{l}\text { Do you think that the activities in favour of the environmental protection are more } \\
\text { important than scientific and technological development? }\end{array}$} \\
\hline yes, definitely & 3.9 & 18.1 & 7.9 \\
\hline yes, I think so & 38.6 & 37.0 & 37.8 \\
\hline no, I don't think so & 39.4 & 29.1 & 29.9 \\
\hline no, definitely & 11.0 & 3.1 & 10.2 \\
\hline difficult to say & 7.1 & 12.6 & 14.2 \\
\hline \multicolumn{4}{|c|}{$\begin{array}{c}\text { Do you think that the activities in favour of the environmental protection are more } \\
\text { important than terrorism prevention? }\end{array}$} \\
\hline yes, definitely & 8.6 & 21.3 & 12.8 \\
\hline yes, I think so & 12.5 & 19.7 & 22.4 \\
\hline no, I don't think so & 40.6 & 33.9 & 35.2 \\
\hline no, definitely & 29.7 & 20.5 & 22.4 \\
\hline difficult to say & 8.6 & 4.7 & 7.2 \\
\hline \multicolumn{4}{|c|}{$\begin{array}{l}\text { Do you think that the activities in favour of the environmental protection are more } \\
\text { important than political changes in your country? }\end{array}$} \\
\hline yes, definitely & 18.8 & 38.5 & 28.3 \\
\hline yes, I think so & 27.3 & 30.0 & 26.0 \\
\hline no, I don't think so & 31.3 & 20.8 & 26.0 \\
\hline no, definitely & 14.1 & 4.6 & 12.6 \\
\hline difficult to say & 8.6 & 6.2 & 7.1 \\
\hline \multicolumn{4}{|c|}{$\begin{array}{l}\text { Do you think that the activities in favour of the environmental protection are more } \\
\text { important than the cultivation of cultural traditions? }\end{array}$} \\
\hline yes, definitely & 10.2 & 27.3 & 21.8 \\
\hline
\end{tabular}




\begin{tabular}{|c|c|c|c|}
\hline yes, I think so & 38.6 & 33.6 & 26.6 \\
\hline no, I don't think so & 33.1 & 25.8 & 25.8 \\
\hline no, definitely & 11.8 & 6.3 & 14.5 \\
\hline difficult to say & 6.3 & 7.0 & 11.3 \\
\hline
\end{tabular}

Source: own data [10]

Data presented in table 4, on the first variable show that the activities in favour of the environmental protection were much more important than economic development for the students from Slovakia and less important for the students from Ukraine, whereas the opinions' of Polish students varied. As a result of the in-depth analysis of these variables (which was possible thanks to the distribution of the answers) and of the chi-squared test, the following value was obtained $\chi^{2}(8)=33.139 ; p<0.05$. These results lead to the formulation of the hypothesis according to which the variable: the country in which the respondents live shapes students' opinions about the significance of the activities in favour of the environmental protection. As the value of the Pearson's Contingency Coefficient $C=0.282$, the adjusted value of the coefficient $\mathrm{C}=0.330$, the strength of the relationship between the variables can be classified as moderate.

In the case of the second variable, i.e. the importance of scientific and technological development, the highest proportion of students who gave more importance to the environmental protection than to scientific and technological development came, again, from Slovakia. However, the proportion was lower than for the variable: the importance of economic development. The value of the chi-squared test was $\chi^{2}(8)=25.177 ; p=0.001$. Thereby, the result of the test is statistically significant, which leads to the formulation of the following hypothesis: the variable: the country in which the respondents live shapes students' opinions about the importance of the activities in favour of the environmental protection. As the value of the Contingency Coefficient $\mathrm{C}=0.249$, the adjusted value of the coefficient $\mathrm{C}=0.291$, the strength of the relationship between the variables can be classified as moderate.

Analysing another variable, i.e. terrorism prevention, the majority of the respondents, regardless of the country in which they live, were of the opinion that the activities in favour of the environmental protection are less important than terrorism prevention. The highest proportion of students who expressed this opinion came from Poland, slightly lower - from Ukraine and the lowest - from Slovakia. It is worth noticing that when nature is placed next to other important social values or threats, the environmental problems become less important for the respondents. In this case the value of the chi-squared test was $\chi^{2}=15.929$ with the degrees of freedom $\mathrm{df}=8$ and the asymptotic significance of $\mathrm{p}=0.043$. Thereby, the result of the test is statistically significant, which leads to the formulation of the following hypothesis: the variable: the country in which the 
respondents live shapes students' opinions about the importance of the activities in favour of the environmental protection. As the value of the Pearson's Contingency Coefficient $\mathrm{C}=0.201$, the adjusted value of the coefficient $\mathrm{C}=0.235$, the strength of the relationship between the variables can also be classified as moderate.

Taking into account another variable, i.e. political reconstruction, we arrive at the conclusion that more than half of the respondents from Slovakia and Ukraine decided that the environmental protection was more important than political changes in their countries, whereas Polish students' opinions varied. Further analysis of these variables, by means of the chi-squared test, resulted in obtaining the following value $\chi^{2}(10)=20,581 ; p=0.024$. Therefore, there is a statistically significant dependence between the variable: the country in which the respondents live and students' opinions about the importance of the environmental protection. As the value of the Contingency Coefficient $\mathrm{C}=0.225$, the adjusted value of the coefficient $\mathrm{C}=0.263$ the strength of relationship between the variables is classified as moderate.

Data on the last variable, i.e. cultivating cultural traditions, show that the vast majority of the respondents give more importance to the environmental protection than to cultivating traditions. The highest proportion of the respondents who expressed this opinion came from Slovakia. The same opinion was expressed by nearly half of the students from Poland and Ukraine. In this case the value of the chi-squared test was $\chi^{2}(8)=20,501 ; p=0.009$. The result of the test leads to the formulation of the hypothesis according to which the relationship between the variable: the country in which the respondents live and students' opinion about the importance of activities in favour of the environmental protection, does exist. As the value of the Pearson's Contingency Coefficient $C=0.227$, the adjusted value of the coefficient $C=0.265$, the strength of the relationship between the variables is moderate.

Table 5. Data presenting the frequency of actions in favour of the natural environment undertaken by the respondents (data expressed in \%)

\begin{tabular}{|c|c|c|c|}
\hline \multicolumn{4}{|c|}{ What do you do in favour of the natural environment? } \\
\hline I am a member of environmental associations & Poland & Slovakia & Ukraine \\
\hline I am a member of a political party that is pro- \\
environmental & 0 & 0.7 & 0.4 \\
\hline $\begin{array}{c}\text { I reprimand people/inform adequate services } \\
\text { about deviant behaviour of other people } \\
\text { towards the environment/animals }\end{array}$ & 2.8 & 1.5 & 0.4 \\
\hline $\begin{array}{c}\text { I take part in events like „Clean up the world” } \\
\text { or „Earth day” }\end{array}$ & 1.6 & 2.2 & 3.8 \\
\hline I buy organic products & 2.6 & 4.2 & 7.6 \\
\hline
\end{tabular}




\begin{tabular}{|c|c|c|c|}
\hline $\begin{array}{l}\text { I limit my needs (I use electricity and water } \\
\text { moderately) }\end{array}$ & 10.7 & 13.5 & 15.1 \\
\hline I separate waste & 20.0 & 17.0 & 5.3 \\
\hline I used energy-saving bulbs & 18.6 & 16.3 & 12.4 \\
\hline $\begin{array}{l}\text { I use environmentally friendly means of } \\
\text { transport (e.g. a bike) }\end{array}$ & 6.6 & 5.5 & 7.9 \\
\hline I use reusable bags when I go shopping & 15.5 & 17.4 & 12.4 \\
\hline I am vegetarian & 0.6 & 1.2 & 0.9 \\
\hline I do not litter & 20.1 & 19.3 & 26.3 \\
\hline I do nothing for the natural environment & 0.4 & 1.1 & 1.7 \\
\hline
\end{tabular}

Source: own data [10]

The analysis of the distribution of the answers presented in table 5, shows that the respondents declared to have a pro-environmental attitude. However, in the case of the students from Poland and Slovakia, it seems to be driven by the binding EU laws. High proportion of Polish and Slovak students answered, e.g. "I segregate waste", whereas this answer was not selected that many times by the students from Ukraine. The answer: "I use energy-saving bulbs" was also selected by a high proportion of the respondents. Apart from the legal requirement, such behaviour may be determined by the need of taking care of the environment and also by the economic factor. Moreover, the proenvironmental attitude of the respondents is very often expressed in activities that are very simple and do not require a lot of effort and commitment, e.g. "I do not litter" was the most frequently selected answer by the respondents from all countries. Other, very frequently selected answers, were: "I use reusable bags when I go shopping" and "I limit my needs", with the latter being most frequently selected by the Ukrainian students who are most willing to live modest lives. The reason for this is the fact that they are relatively the poorest among all the groups that took part in the research. Therefore, they are more willing to limit their needs than the students living in richer consumerist societies. Only small proportion of the respondents declared to be more active in favour of the environment, e.g. being a member of a "green party" or reprimanding others for deviant behaviour towards the environment. However, what should instil optimism is the fact that only few respondents said that they did nothing in favour of the natural environment. It is difficult to decide whether the variable: the country in which the respondents live has a significant impact on the pro-environmental attitudes declared by the respondents. Although the highest proportion of the answers (in the largest number of categories) were selected by the students from Ukraine, the differences in how often the answers in these categories were selected (apart from the answer: "I do not litter") were not significant when we compare students from Ukraine with the students from Poland and Slovakia. 
Table 6. Data illustrating consumer habits declared by the students (data expressed in \%)

\begin{tabular}{|c|c|c|c|}
\hline \multicolumn{4}{|c|}{ Which behaviour is the most characteristic for you? } \\
\hline $\begin{array}{c}\text { I always buy products that are new on the } \\
\text { market - it makes me feel better. }\end{array}$ & 2.5 & 7.9 & 2.6 \\
\hline $\begin{array}{c}\text { If I could afford it, I would only buy products } \\
\text { that are new on the market. }\end{array}$ & 14.0 & 10.3 & 20.0 \\
\hline $\begin{array}{c}\text { I often buy various things but they are always } \\
\text { on sale - with the lowest price possible. }\end{array}$ & 11.6 & 6.3 & 3.5 \\
\hline $\begin{array}{c}\text { I try to save up so that I can sometimes buy } \\
\text { something of good quality that will last longer. }\end{array}$ & 38.8 & 34.9 & 33.0 \\
\hline $\begin{array}{c}\text { Although I can afford many things, I do not } \\
\text { have great needs. I only buy things that I really } \\
\text { need or when the old ones get used up or are } \\
\text { broken. }\end{array}$ & 28.9 & 32.5 & 28.7 \\
\hline $\begin{array}{c}\text { I very rarely buy new things. Usually I try to } \\
\text { fix old things. }\end{array}$ & 4.1 & 4.8 & 5.2 \\
\hline $\begin{array}{c}\text { Price does not matter to me. I choose ,organic } \\
\text { products” - I always read labels. }\end{array}$ & 0 & 3.2 & 7.0 \\
\hline
\end{tabular}

Source: own data [10]

The analysis of the data presented in table 6 shows that, regardless of the variable: the country in which the respondents live, the answer "I try to save up so that I can sometimes buy something of good quality that will last longer" was selected by the highest proportion of the students. Such behaviour may be regarded as a sign of a pro-environmental attitude, however, it is difficult to decide whether the students are mainly motivated by the environmental or economic factors. Slightly lower proportion of the respondents selected the answer: "Although I can afford many things, I do not have great needs. I only buy things that I really need or when the old ones get used up or are broken". Such an attitude can also be regarded as pro-environmental. It proves that the respondents are able to limit their needs and they are willing to live modest lives. What is interesting is the fact that during self-evaluation of the financial situation only a small proportion of the respondents claimed that they lived very good or even prosperous lives. However, when asked about the consumer habits, nearly $1 / 3$ of the respondents claimed that "(...) they can afford many things (...)". Obviously, the evaluation was very subjective, which means that even relatively poor respondents may think they can afford a lot. At the same time, it is quite worrying that only a few respondents (and these were the students from Ukraine) claimed that they read labels of the products they buy. However, what should instil optimism is the fact that only a small proportion of the respondents are spendthrift. However, we may assume that the first three answers were selected by lower proportion of the respondents, as they did not want to admit to 
"bad" consumer habits. Therefore, we need to emphasise that the declarations made by the students may, to a certain extent, differ from their real everyday consumer habits. The value of the chi-squared test was $\chi^{2}(12)=24.598 ; p=0.017$. Thereby, the result of the test is statistically significant, which leads to the formulation of the hypothesis according to which the variable: the country in which the respondents live correlates with the consumer habits of the respondents. As the value of the Pearson's Contingency Coefficient $\mathrm{C}=0.252$, the adjusted value of the coefficient $\mathrm{C}=0.263$, the strength of the relationship between the variables can be classified as moderate.

Table 7. Data illustrating students' opinions about the relation between a man and the nature (data expressed in \%)

\begin{tabular}{|l|c|c|c|}
\hline \multicolumn{4}{|c|}{ Which of the following statement is closest to you? } \\
\hline $\begin{array}{l}\text { God ordered a man to make the Earth } \\
\text { dependent. Therefore, we can change or } \\
\text { exploit it without any restrictions. }\end{array}$ & 2.3 & 0.8 & 2.5 \\
\hline $\begin{array}{l}\text { A man cannot use gifts of nature mindlessly, } \\
\text { as their only Master is God. }\end{array}$ & 1.6 & 1.6 & 5.0 \\
\hline $\begin{array}{l}\text { Nature is the gift of God and a man should feel } \\
\text { responsible for it and use it wisely. }\end{array}$ & 40.6 & 44.5 & 27.7 \\
\hline $\begin{array}{l}\text { A man, as the most advanced creature, thanks } \\
\text { to their intellect and dexterity, has the right to } \\
\text { use the natural resources without any } \\
\text { restrictions. }\end{array}$ & 3.9 & 0.8 & 1.7 \\
\hline $\begin{array}{l}\text { A man, as a moral being, should take care of } \\
\text { the nature and use its abundance moderately. }\end{array}$ & 40.6 & 39.1 & 52.9 \\
\hline $\begin{array}{l}\text { A man, like other species, is an element of the } \\
\text { nature. Therefore, we should not place our } \\
\text { needs higher than the needs of other creatures } \\
\text { and we should also limit our needs. }\end{array}$ & 10.9 & 13.3 & 10.1 \\
\hline $\begin{array}{l}\text { Source: own dat [10] } \\
\text { Pand }\end{array}$ & & & \\
\hline
\end{tabular}

Source: own data [10]

The distribution of the answers presented in table 7 shows that the variable: the country in which the respondents live, to a certain extent, differentiates students' opinions about the relation between a man and the nature. The answer: "Nature is the gift of God and a man should feel responsible for it and use it wisely" was most frequently selected by the students from Slovakia and slightly less frequently by the students from Poland. The answer: "A man, as a moral being, should take care of nature and use its abundance moderately" was most frequently selected by the Ukrainian students and slightly less frequently by the students from Poland. The fact that the Ukrainian students more often selected "moral statement" rather than "religious statement" may be surprising. This means, however, that the correlation between Orthodoxy (86.8\%) and "religious 
statement" is not significant. The relationship between the variable: religion and the statement selected by the Polish and Slovak students is only slightly stronger (98.5\% of Polish and $83.8 \%$ of Slovak students declared to be Catholics). What can instil optimism is the fact that, regardless of the religious or moral context, only a few respondents agreed with the opinion that we could exploit nature without any restrictions. Finally, it is worth noticing that a certain proportion of the respondents selected the last statement, which means that they are in favour of the equal treatment of all species on Earth (so called environmental egalitarianism) without putting homo sapiens higher than other creatures.

\section{CONCLUSIONS}

To conclude, on the basis of the conducted research we can state, that:

1. The students of Central and Eastern Europe generally declared interest the state of the environment. The opinions expressed by students during the researches may differ from the real attitudes of respondents.

2. The overall outcome of the research leads to the conclusion that the highest proportion of the respondents who declared interest in the environmental protection came from Slovakia.

3. The fact that in their opinion it should care about the environment more than the students from Poland and Ukraine may result from the higher level of the environmental awareness. Relatively "poor" results obtained by the students from Poland and Ukraine may be explained by the fact that when the state of the environment is satisfactory, the environmental awareness is not that strong in a groups. The poor state of the awareness of Polish and Ukrainian students may also result from inadequate level of environmental education.

4. We can state that although, in general, the respondents were in favour of taking care of the natural environment, their environmental awareness is still in the phase of formation and does not have the ground position in the social awareness of the respondents.

5. Finally, it needs to be pointed out that the fact that the respondents took part in the research on the environment and the environmental protection may have, to a certain extent, raised their environmental awareness. In the face of this, the research may have served a positive function.

\section{REFERENCES}

1. Altin A., Tecer S., Tecer L., Altin S., Kahraman B. F., Environmental awareness level of secondary school students: A case study in Balikesir (Turkiye), Procedia - Social and Behavioral Science, 2014, 141, pp. 12081214. 
2. Cetin G., Nisanci S. H., Enhancing students' environmental awareness, Procedia - Social and Behavioral Sciences, 2010, 2, pp. 1830-1834.

3. GEO5 Global Environment Outlook, Environment for the future we want, United Nations Environment Programme, (http://web.unep.org/geo/sites/unep.org.geo/files/documents/geo5_report_full _en_0.pdf, dostęp 11.12.2016).

4. Hassan A. A., Noordin T. A., Sulaiman S., The status on the level of environmental awareness in the concept of sustainable development amongst secondary school students, Procedia - Social and Behavioral Sciences 2010, 2(2), pp. 1276-1280.

5. Liu Z., Anderson T. D., Cruz J. M., Consumer environmental awareness and competition in two-stage supply chains, European Journal of Operational Research, 2012, vol. 218, No 3, pp. 602-613.

6. Kielczewski D., Ekologia spoleczna, Bialystok, p. 20, as cited [in:] Malachowski K. (ed.), Gospodarka a srodowisko i ekologia, Warszawa 1999, p. 35.

7. Özden M, Environmental awareness and attitudes of student teachers: An empirical research, International research in geographical and environmental education, 2008, vol. 17, pp. 40-55.

8. Papuzinski A., Świadomość ekologiczna w świetle teorii i praktyki, Problemy Ekorozwoju, 2006, t. 1, nr 1, s. 29-41.

9. Zhang W., Kato E., Phandary P., Nkonya E., Ibrahim H. S., Agbonlahor M., Ibrahim H. Y., Cox C., Awareness and perceptron of ekosystem services in relation to land use types. Evidence from rural communities in Nigeria, Ecosystem Services, 2016, vol. 22, pp.150-160.

10.The funds for the article and the sociological research came from the designated subsidy of the Ministry of Science and Higher Education, project number: IS-01/2015/508.

\section{STAN ŚWIADOMOŚCI ŚRODOWISKOWEJ STUDENTÓW Z POLSKI, SŁOWACJI I UKRAINY - WYBRANE WYNIKI}

\section{Streszczenie}

W artykule przedstawione zostały wyniki międzynarodowych badań na temat świadomości środowiskowej. Projekt został zrealizowany w roku 2015. Głównym celem niniejszego artykułu jest opisanie poziomu wiedzy, akceptowanych wartości i postaw studentów z Europy Środkowej i Wschodniej względem przyrody. We wstępie artykułu zdefiniowano pojęcie świadomości środowiskowej. 
Problem badawczy został sformułowany w następujący sposób: Jakie występują różnice W stanie świadomości środowiskowej między respondentami z Polski, Słowacji i Ukrainy? W pierwszej części artykułu przedstawiona została metodologia przeprowadzonych badań. Druga część tekstu dotyczy analizy zebranych danych. Na jej podstawie można stwierdzić, że wybrani studenci z Europy Środkowej i Wschodniej ogólnie wykazywali zainteresowanie stanem środowiska przyrodniczego. Przeprowadzona analiza statystyczna pozwala również na sformułowanie wniosku, iż najwyższy odsetek respondentów, którzy deklarowali zainteresowanie ochroną środowiska stanowili słowaccy studenci. Fakt ten świadczy o tym, iż respondenci ze Słowacji prezentowali wyższy poziom świadomości środowiskowej niż studenci $\mathrm{z}$ Polski i Ukrainy.

Słowa kluczowe: świadomość środowiskowa, stan środowiska przyrodniczego, badania socjologiczne, socjologia środowiska

Editor received the manuscript: 09.09.2016 